\title{
Prospects for upgrading by the European kelp sector
}

\author{
Sander van den Burg ${ }^{1}$ (D) $\cdot$ Trond Selnes $^{1} \cdot$ Liliana Alves $^{2} \cdot$ Else Giesbers $^{1} \cdot$ Ana Daniel $^{3}$
}

Received: 25 September 2020 / Revised and accepted: 26 October 2020 / Published online: 17 November 2020

(C) The Author(s) 2020

\begin{abstract}
The interest in cultivating seaweed in European seas as source of food, feed and feedstock for the biobased economy is growing. Amongst the species investigated is kelp, also known as sugar kelp, Saccharina latissima or Laminaria saccharina. The European kelp sector is relatively small, compared to the global production and use, yet growth of the sector is aimed for. An inevitable question for European seaweed producers is how they can compete in the global seaweed value chain. This paper assesses to what extent the European strategy for growing the kelp sector matches with the dynamics of current kelp value chain. The global value chains (GVC) framework is applied to study how the global kelp sector is organized, including analysis of trends in science and patents. The upgrading strategy deployed by the European sector is critically evaluated against this framework. The analysis points towards various dividing lines between the established kelp cultivation and processing industry in Asia and the (far smaller) nascent cultivation and processing industry for high-value applications. These represent two unconnected worlds. Chain or intra-sectoral upgrading to spur the European kelp sector could occur if European food sector engage more closely with the European producers. Those bring financial power and a broader client base to the table and are instrumental in linking production to the demands of end-users.
\end{abstract}

Keywords Seaweed $\cdot$ Saccharina $\cdot$ Market $\cdot$ Value chain $\cdot$ Governance $\cdot$ Patents

\section{Introduction}

There is a rising interest in cultivating seaweed in the European seas (Buck et al. 2004; van den Burg et al. 2016; Bak 2018). Seaweeds are expected to be used in a range of fields: food (Nayar and Bott 2014; Roleda et al. 2010), feed (Mac Monagail et al. 2018), feedstock for the biobased economy (Stévant et al. 2017; Helmes et al. 2018), pharmaceutical applications (Kang et al. 2016), cosmetics (Couteau and Coiffard 2016) and bioremediation i.e. removing pollutants from the aquatic environment (Elizondo-González et al. 2018).

The rising interest is stimulated by the European Blue Growth strategy and national and regional development strategies, such as of the Dutch Proseaweed program (van den

Sander van den Burg

sander.vandenburg@wur.nl

1 Wageningen Economic Research, PO Box 29703, 2525, LS The Hague, the Netherlands

2 DEGEIT, University of Aveiro, Campus Universitário Santiago, 3810-193 Aveiro, Portugal

3 GOVCOPP, DEGEIT, University of Aveiro, Campus Universitário Santiago, 3810-193 Aveiro, Portugal
Broek and van Swam 2018), yet seaweed production and use in Europe are, with the exception for food thickeners produced from wild harvested seaweeds, still a minor sector in terms of volumes and value. Outside of Europe, the production and consumption of seaweeds are a long-established business (Porse and Rudolph 2017). South-East Asia is the main producing region, where China and Indonesia are by far the biggest producers (Buschmann et al. 2017), although production also occurs in parts of Africa (Bindu and Levine 2011; Msuya et al. 2014) and South-America (Buschmann et al. 1996).

As Europe aims to increase its seaweed industry, European seaweed producers question how they can compete in the global seaweed value chain. Some studies focus on the costs of production and critically questioned the competitiveness of European producers in the global market based on price (van den Burg et al. 2016; Bak 2018). Van Leeuwen (2018) acknowledges that his company Seaweed Harvest Holland faced a huge challenge to get production costs down to Asian levels. In June 2020, the company had to file for bankruptcy. According to Tallman et al. (2018), competitiveness in global value chains is however not a matter of having the lowest production costs, but a matter of generating sufficient value. To this end, upgrading strategies are essential, i.e. to move to 
higher value activities and market segments (Gereffi and Lee 2016). In this context, significant efforts are undertaken to develop high-value products from European seaweeds, catering to the cosmetics, pharmaceutical, bio-stimulant, highgrade alginate and bioplastic markets (Hanbidge et al. 2016). Framed in the terminology of Gereffi and Fernandez-Stark (2016), this is about product upgrading, moving into more sophisticated product lines. For instance, Faroer-based producer Ocean Rainforest explores various markets for seaweed-based products, with the food and fucoidan markets as two highest valued markets with respectively estimated prices for seaweed between 20.000 and $50.000 €$ per tonne dry weight (Gregersen 2018). French seaweed processor Algaia seeks to increase value from its produce through development of new biorefinery processes (News Desk 2018). Portuguese seaweed producer Algaplus has launched its own consumer brand 'Tok de Mar' to sell parts of its produce on the high-value local consumer market.

This paper aims to assess to what extent this strategy to develop high-value products from European cultivated matches with the dynamics of current global kelp value chain. The main research question is: what is the viability of the upgrading strategy currently deployed by the European kelp sector?

To answer this main question, the following sub-questions are identified and addressed:

- What are the trends in seaweed research, including topical and geographic focus?

- What are the trends in patents related to kelp?

- What are the governance strategies deployed in the current kelp value chains?

- How do these developments impact the future development of the European kelp sector?

This paper describes the case of kelp, and as much as possible focusses in particular on Saccharina spp., a seaweed that can be produced in Europe for the global markets. Saccharina spp. are nowadays commonly processed for the production of alginate, a biomaterial that has found numerous applications in biomedical science and engineering due to its favourable properties, including biocompatibility and ease of gelation (Lee and Mooney 2013). Various studies have confirmed the potential of using Saccharina spp. in other markets such as food, green chemicals and pharmaceuticals (Adams et al. 2009; Ehrig and Alban 2015; Lüning and Mortensen 2015).

\section{Methodology}

\section{Conceptual framework}

The global value chains (GVC) framework is used to study how global industries are organized, examining the structure and dynamics of different actors involved in a given industry (Gereffi and Fernandez-Stark 2016). A value chain is defined as the 'full range of activities that firms and workers do to bring a product from its conception to its end use and beyond' (Gereffi and Fernandez-Stark 2016, p. 7) and typically includes a variety of activities: design, production, marketing, distribution and support to the final consumer. These activities can be performed within the same firm or divided amongst different firms - emphasised by the notion of a chain. The fact that they are increasingly spread over different countries and continents explains why the value chain is regarded as 'global' (De Backer and Miroudot 2012).

Competitiveness in global value chains can be reached through a 'low road' (fight competitors based on low costs) and a 'high road' which, in this last case, comprises innovation, increasing productivity and enhancing quality (Milberg and Houston 2005). The high road requires the use of upgrading strategies to increase the value of produced materials. Drawing on Humphrey and Schmitz (2002), Gereffi and Fernandez-Stark (2016) identify seven upgrading strategies:

- Process upgrading, increasing the efficiency with which inputs are transformed into outputs;

- Product upgrading, moving into more sophisticated product lines;

- Functional upgrading, acquiring new functions to increase the overall skill content of the activities;

- Chain or intra-sectoral upgrading, where firms move into new but often related industries;

- Entry into the value chain, where firms participate for the first time in existing value chains;

- Backwards linkages upgrading, where local forms in one industry begin to supply tradable input and/or services that are located in the country;

- End-market upgrading, which can include moving into more sophisticated markets that require compliance with new, more rigorous standards.

Upgrading strategies must fit within the organisation of the value chain. Value chain analysis is used to characterise value chains, focusing on, in addition to upgrading strategies, the (i) input-output structure, which includes matters as research, production, sales; (ii) geographic scope of supply and demand; (iii) governance, with focus on the ability to control and coordinate market influence; (iv) the institutional context, which is about conditions and policy and (v) stakeholder involvement (Gereffi et al. 2005; Gereffi and Fernandez-Stark 2016).

In this article, we focus explicitly on three dimensions: scientific research; the patents and the governance of the value chain, which includes an analysis of main actors and relationship between them.

\section{Trends in science}

A systematic literature review was conducted to investigate research and innovation on Saccharina spp., including an 
analysis of geographical distribution and the number of publications per year. Systematic reviews aim to identify, critically evaluate and integrate the findings of all relevant, highquality individual studies addressing one or more research questions (Siddaway 2014). The number and focus of scientific publications were used as an indicator for innovation in the kelp producing and processing sector.

To search for these scientific publications, Scopus was used to search for all scientific publications published between 1990 and 2019, with the search terms 'Saccharina latissima' OR 'sugar kelp' OR 'Laminaria saccharina' in abstract, title and keywords. Because we noticed that not all abstracts and keywords specified what kind of seaweed the article focussed on, we also ran Scopus with the following, more general search terms: 'seaweed' OR 'macro-algae' OR 'macroalgae' OR 'brown macro-algae' OR 'green macro-algae' OR 'brown macroalgae' OR 'green macroalgae' OR 'Saccharina latissima' OR 'Ulva'. Both combinations of search terms were used for the following categories: 'Pharmaceuticals', 'Pharmaceuticals AND Fucoxanthin', 'Bioplastics OR Bioplastics', 'Biostimulant OR bio-stimulant', 'Alginate', 'Cosmetics' and 'Cosmetics AND antioxidant OR anti-oxidant'. For each category, overviews of the geographical distribution by continent and the number of articles published each year were produced.

\section{Patent analysis}

Patent analysis was carried out to identify the key players (holders), investment trends (number of patent applications) and patents technology domains related to kelp. The Orbit Intelligence software was used, which has a database of patents translated into English from over 100 countries. The advanced search option of the Orbit Intelligence allows keyword research in different fields of the patent (title, abstract, claims, etc.) combined with other fields, such as classifications (international classification, technology domain, etc.); names (assignees, inventor, representative); numbers, dates and countries (publication number, publication date, priority number, priority dates, etc.); legal status (status, legal events, expiration date). The Automatic Semantic search was used to check all denominations related to Saccharina spp. Thus, we identified the three most used names in the publications of patents: 'Saccharina latíssima' OR 'Sugar Kelp' OR 'Laminaria saccharina'. First, we searched these three denominations in four fields: title, abstract, claims, descriptions. Next, we restricted the search only to the granted patents and, last, we consulted the pending patents, to analyse the future trends.

In Table 1, we present the summary of the commands used throughout the search.

In each search, the Orbit Intelligence generated a listing of all the patents families that fit the commands. These outputs allowed the access to data such as: investment trends, key players and technology domains, as well as market and competitors location.

\section{Governance of the value chain}

We follow Gereffi (1994, p. 97) and his definition of governance as 'authority and power relationships that determine how financial, material and human resources are allocated and flow within a chain'. The GVC literature identified five types of governance structures each with different relationships between the actors, suppliers, intermediaries and the lead firm (see Fig. 1). In the market type, multiple suppliers provide to multiple firms and transactions take place in an open market place. In the modular type, intermediaries provide to the lead firm based on codified product characteristics whereas in the relational type, the production characteristics are defined together. The captive type is characterised by lead firm control over de suppliers and in the hierarchy type, one company takes control over primary production (Gereffi et al. 2005; Gereffi and Fernandez-Stark 2016, p.12).

\section{Results}

\section{Trends in science}

Figure 2 shows the modest increase in the number of publications regarding Saccharina latissima OR sugar kelp OR Laminaria saccharina over the last 29 years. This upward trend starts to manifest around 2010. Before 2010, scientific publications did not touch upon the topics of bioplastics, pharmaceuticals or cosmetics. Since then, these subjects have gained more attention, notwithstanding the fact that research into alginate is still an important constituent of the total number of publications.

If we assume that some publications do not specify what kind of seaweeds are studied, and instead refer to the more generic term 'seaweed', the picture sketched above is amplified (see Fig. 3) showing a significant increase in the number of publications, most strongly in the fields of pharmaceuticals and alginate.

Pharmaceuticals have now peaked to above 100, and alginate seaweed is also close to 100 . Since 2014, also, biostimulant is rising substantially, but bioplastics and cosmetics are still very low in numbers.

Figure 4 shows the geographical origins of the papers published on Saccharina latissima OR sugar kelp OR Laminaria saccharina. Europe is well represented in relation to pharmaceuticals, alginate and cosmetics. The biostimulant sector differs, with an equal distribution of papers over North America and Asia. Since there are no scientific papers published for bioplastics, this market is not included in Fig. 4. 
Table 1 Search commands performed on Orbit Intelligence

\begin{tabular}{ll}
\hline Step & Command \\
\hline 1 & $\begin{array}{l}\text { Saccharina latissima OR Sugar Kelp OR Laminaria saccharina/FIELD: Title, Abstract, Claims, } \\
\text { Descriptions }\end{array}$ \\
2 & $\begin{array}{l}\text { Saccharina latíssima OR Sugar Kelp OR Laminaria saccharina/FIELD: Title, Abstract, Claims, } \\
\text { Descriptions/Granted }\end{array}$ \\
3 & Saccharina latíssima OR Sugar Kelp OR Laminaria saccharina/FIELD: Title, Abstract, Claims, \\
& Descriptions/Pending
\end{tabular}

If we assume that some publications do not specify what kind of seaweeds are studied, and instead refer to the more generic term 'seaweed', we see that most articles are published in Asia. This revised search term brings up a significant number of publications from Europe on bio-stimulant. For each market, Asian and European publications include more than $65 \%$ of the total amount of publications as can be seen in the following figure (Fig. 5).

\section{Patent analysis}

In search of patent portfolios related to kelp, we found 718 patent families with Saccharina latissima OR Sugar Kelp OR Laminaria saccharina in the title, abstract, claims or description fields of the patents. In 2000, there was the lowest number of patent families' submissions, only 5 , but since the beginning of the new millennium, patent submission in this field has increased, despite oscillations. The highest number of patent submissions was recorded in 2012 with a total of 62 patent families' submissions. The decrease in the last three years can be due to lag time between patent application and publication (Figs. 6 and 7).

Next, we performed an analysis of the technology domains of patent families. As can be seen in the following figure, organic fine chemistry, food chemistry and pharmaceuticals are the technology domains where most patents fit in.

The key players in the analysed scope are L'Oreal, Symrise, ELC Management and Procter and Gamble. The portfolio of patent families is made up of alive patents and dead patents. Dead patents are patents that are no longer in force because they have expired, 20 years, or because current assignees have failed to pay protection fees. The alive patents are divided into two groups: granted and pending. The granted ones are in force and the pending ones are awaiting approval. In order to identify the current key players, we analyse the alive portfolios.

Considering the alive portfolio of patent families, L'Oreal is the company with the most patent families granted (total of 109). In turn, ELC management has 12 patent families granted, Symrise owns 11 and Procter and Gamble has 10. Observing the pending patent families, as foreseen, L'Oreal is the company with more pending patent families (total of 19). The remaining players have very limited number of pending patents.

The content analysis of active patent families owned by L'Oreal disclosed that the portfolio is related with cosmetic products, namely for the skin care, greasy skin and scalp disorders. Patents refer to other plants and oils, such as canola oil, Thymus vulgaris, Sanguisorba officinalis, Saphora japonica. The patents mention squalane, ceramide, zinc salicylate as well. In turn, ELC management's portfolio is also related to cosmetic products for treating the skin and hair. The key words of these patents are caffeine, antioxidant, permethyl, alkenyl group and methyl glucose, as well as alkoxylation and behenyl alcohol reaction.

The Symrise's alive patent families are patents about fragrance composition, stabilized taste and odor, antimicrobial compositions. In addition to patents related to flavour and nutrition, there are also patents related to cosmetics: skin treatment, cosmetic composition for lightening the skin and hair and compounds as active anti-cellulite ingredients. Patents refer to keywords such as anserine, bisabolol, ursolic acid,
Fig. 1 Five types of value chain governance (based on Gereffi et al. 2005)

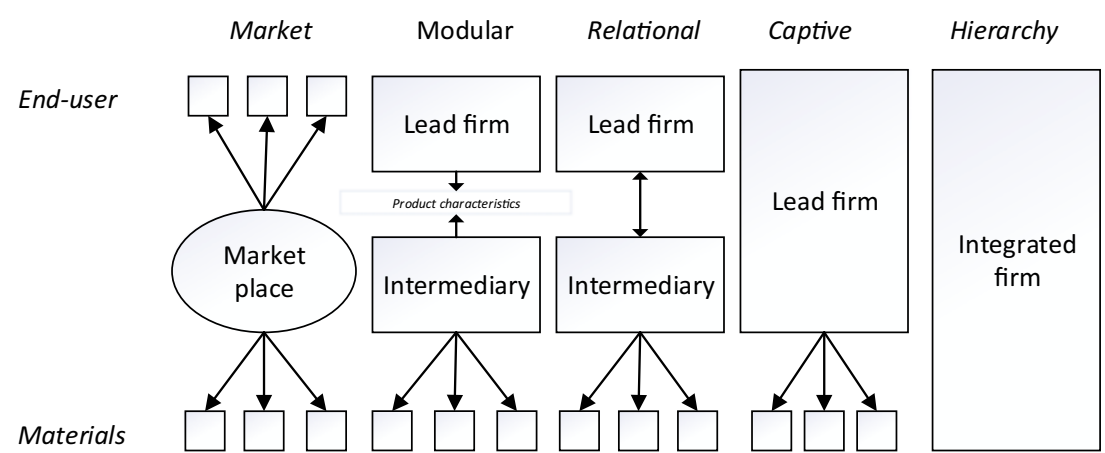




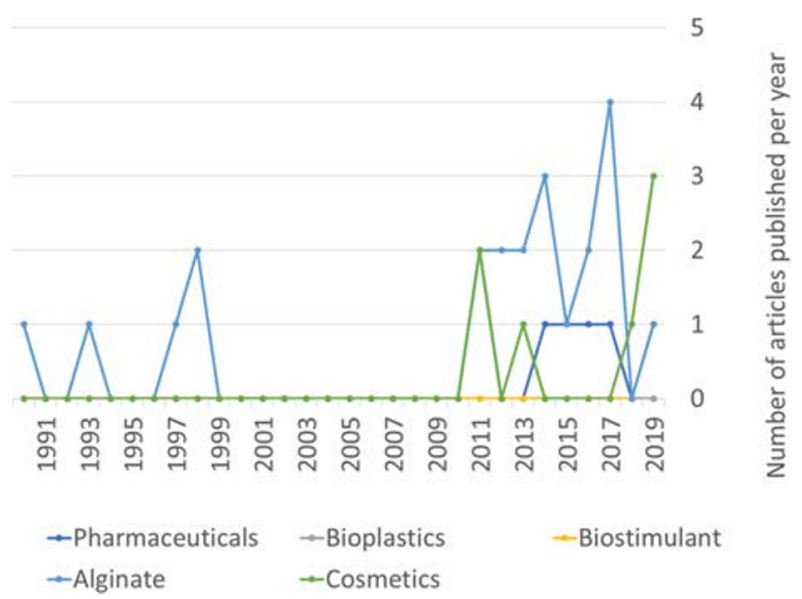

Fig. 2 Developments in number of scientific publication per market over time for Saccharina latissima OR sugar kelp OR Laminaria saccharina

astringent, apple fruit extract, ulva filter, magnesium ascorbyl phosphate, stimulating cell and cholesterol.

The alive patent families owned by Procter and Gamble are related to cosmetic products, namely to hyperpigmented spot(s), freckles. These patent families mention dimethyl aminobenzoate, acetyl mannosamine, acyl phenylalanine derivative, salicyclic acid and dispersibility, mixing ingredient and anti-inflammatory active.

More important than the location of the key players, it is the place where patent protection is applied for. Thus, the countries where there are more patent families protected are France, China, the USA and Japan.

There are 163 patent families protected in France, 139 in China, 134 in the USA, 108 in Japan, 87 in Germany, 77 in the United Kingdom, 59 in South Korea, 51 in Brazil and 49 in
Spain. There are also 149 European patents and 33 Word patents.

Additionally, the search in the alive portfolio of patent families related with Saccharina latissima OR sugar kelp OR Laminaria saccharina and alginate showed that the main protection countries are the USA, Japan, France and China. There are 76 patent families protected in the USA, 57 in Japan, 54 in France, 53 in China, 43 in Germany, 37 in the United Kingdom, 30 in Brazil, 27 in South Korea and 25 in India. Besides these, there are also 72 European patents and 12 world patents.

\section{Governance of the value chain}

When looking at the governance of the kelp value chain, the first observation is that they are currently concentrated in Asia, dominating the seaweed aquaculture with $99 \%$ of the quantity and value (Barbier et al. 2019; FAO 2020). In China various large kelp-companies are involved in the whole seaweed value chain, investing in seeding technology, cultivation, pretreatment processing, storage, distribution and retailing. Cultivation of seaweeds is done by multiple - unidentified companies, most of which operate on a large scale, 3,5006,700 ha (Zhang 2018). Kelp food products are sold in China through wholesale markets, local community markets and e-commerce business channels (Zhang 2018). Following the classification developed by Gereffi et al. (2005) governance in the kelp value chain can be characterised as captive governance, where a few large companies that cover various steps in the supply chain control the value chain.

Various European and the US multinationals are historically active in the production of alginate in regions with abundant

Fig. 3 Developments in number

120 of scientific publications per market over time for seaweed

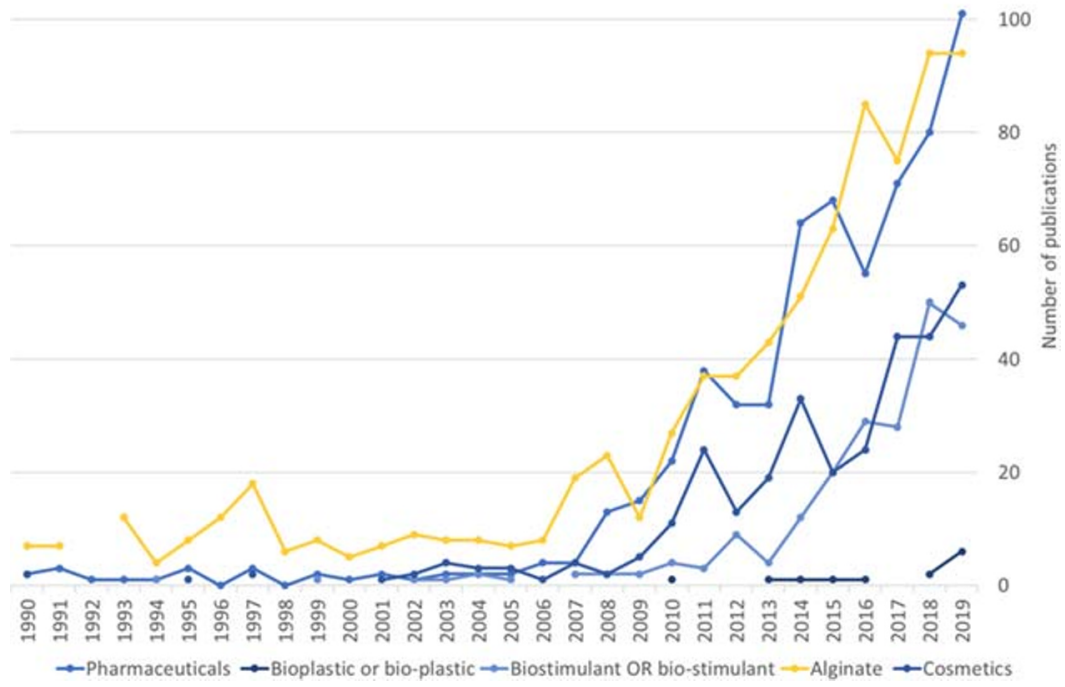


Fig. 4 Developments in share of scientific publications for Saccharina latissima OR sugar kelp OR Laminaria saccharina per market for each continent (bioplastics are excluded since there no publications were found)

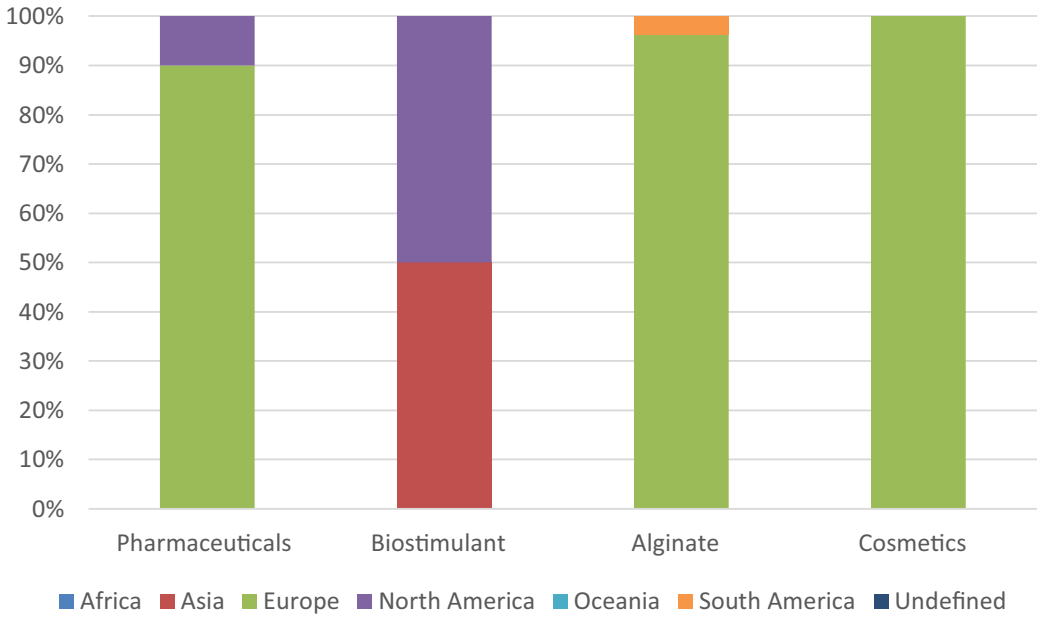

natural seaweed resources. For more than five decades, seaweeds have been the subject of considerable industrial utilization in Norway and France, based on harvesting of natural biomass (Stévant et al. 2017). The situation is different if we look at the nascent seaweed cultivation sector and the new markets for applications of seaweed. Here we see a large number of companies. In production, prime examples of offshore seaweed production now are Ocean Rainforest in the Faroe Islands, described by Bak et al. (2018), as well as the companies Seaweed Energy Solutions, C-Weed in France, the North Sea Farm Foundation's test site in the North Sea. Seaweed cultivation has gained ground in Norway. By January 2017, there were a total of 309 permits for macroalgae cultivation in Norway, of which roughly half were awarded for kelp cultivation (Broch et al. 2019).

This nascent kelp cultivation sector operates in a value chain characterised by network governance. Frequent interaction and collaboration between governments, companies, sector representatives and research organisations, facilitated by subsidies and availability of research funding, is the basis of joint roadmaps and (partly) subsidized pilots (see European
Commission 2018). The Dutch Seaweed Platform was established in 2014 to share knowledge and to facilitate cooperation between companies in various parts of the seaweed value chain. In March 2019, 78 organisations were member of the seaweed platform (Noordzeeboerderij 2020). Energy companies are also involved, which can be explained by their interest in using offshore wind farms to cultivate seaweed (van den Burg et al. 2016).

\section{Discussion}

\section{The global kelp value chain: two different worlds}

From the analysis presented above, multiple dividing lines can be drawn separating distinct elements of the global kelp value chain. A first dividing line is drawn between Asia and the rest of world. Looking at volume and concentration of activities, Asia dominates the global value chain. European (and the USA) alginate producers have a niche in the global market, producing food and pharma-grade alginate. The new

Fig. 5 Developments in share of scientific publications for seaweed per market for each continent

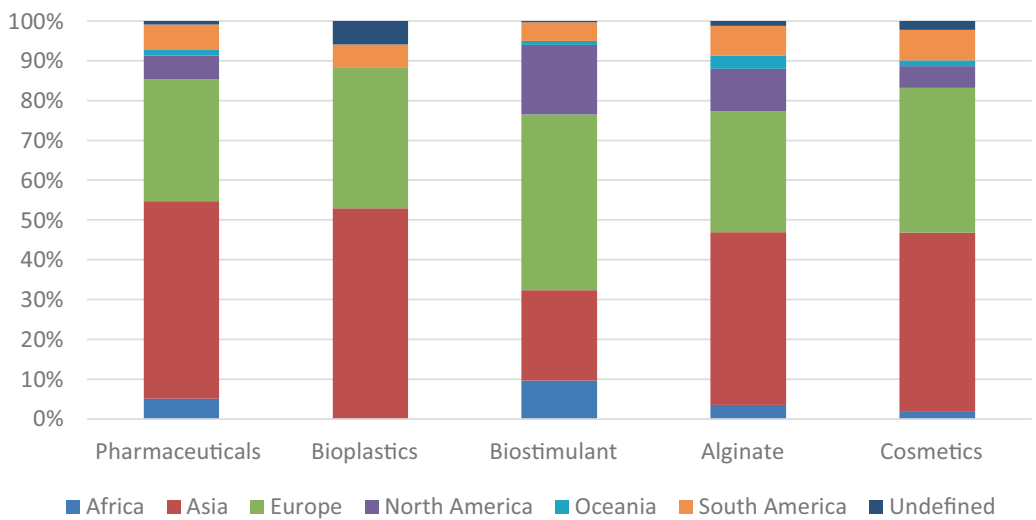


Fig. 6 Saccharina latissima OR sugar kelp OR Laminaria saccharina patent families: investment trend

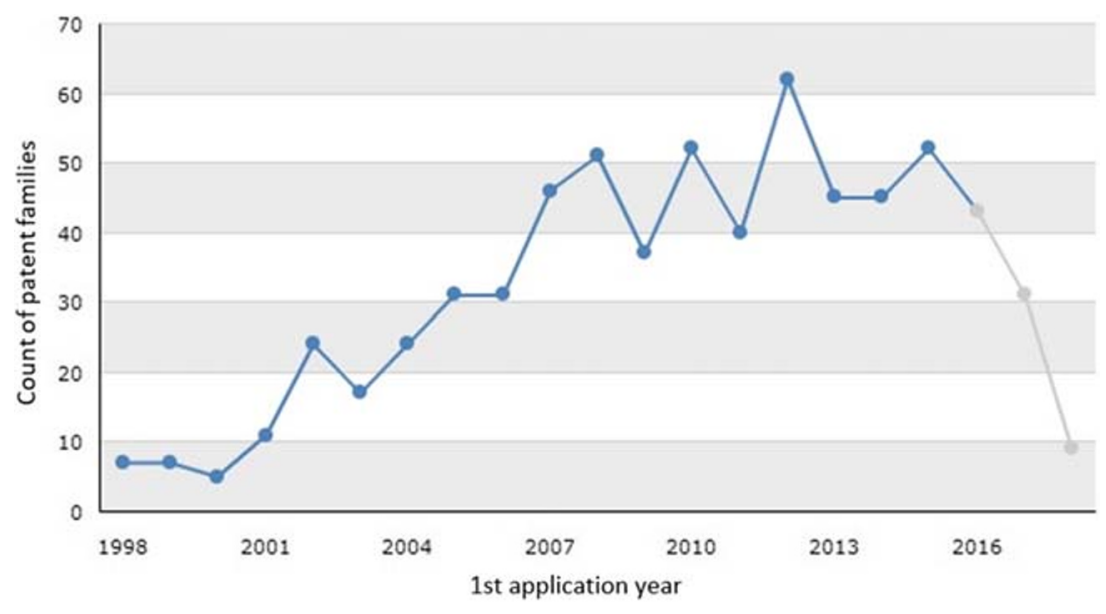

European seaweed sector - venturing into cultivation and various new applications in food and feed-is small in size.

A second dividing line can be drawn between the large integrated seaweed companies that produce, handle, process and market seaweed and the smaller companies that cover only parts of the value chain. In Asia and for the EU/US alginate sector, value chain governance is characterised by powerful lead firms that own or control the entire value chain. New kelp producers and kelp users have little power over the value chain, and are subjected to the wishes and demands of the lead firms in targeted markets.

The multiple dividing lines point to the existence of two distinct, but disconnected kelp value chains. On the one hand, the dominant players are organised in integrated value chain and consolidate their position. On the other hand, new actors have developed a parallel kelp value chain, based on cooperation with other companies and exploration of new kelp application. New producers and processors have to relate to other value chains (e.g. the cosmetics and pharmaceuticals value chains). These are demanding value chains in terms of quality and control. Newcomers might be able to fit into these new markets better than the current global brown seaweed value chain, although the latter might profit from already built up knowledge and capital. Competition between newcomers and the established business is likely to take place and establishing solid links between the world of seaweed and the world of applications such as pharma, cosmetics and bioplastics will be pivotal.

\section{Ambitious upgrading strategy in Europe}

The European kelp sector now aims for the production of high-value products to set up new (global) value chains for seaweed, bypassing the existing and dominant Asian-led
Fig. 7 Saccharina latissima OR sugar kelp OR Laminaria saccharina patent families: technology overview

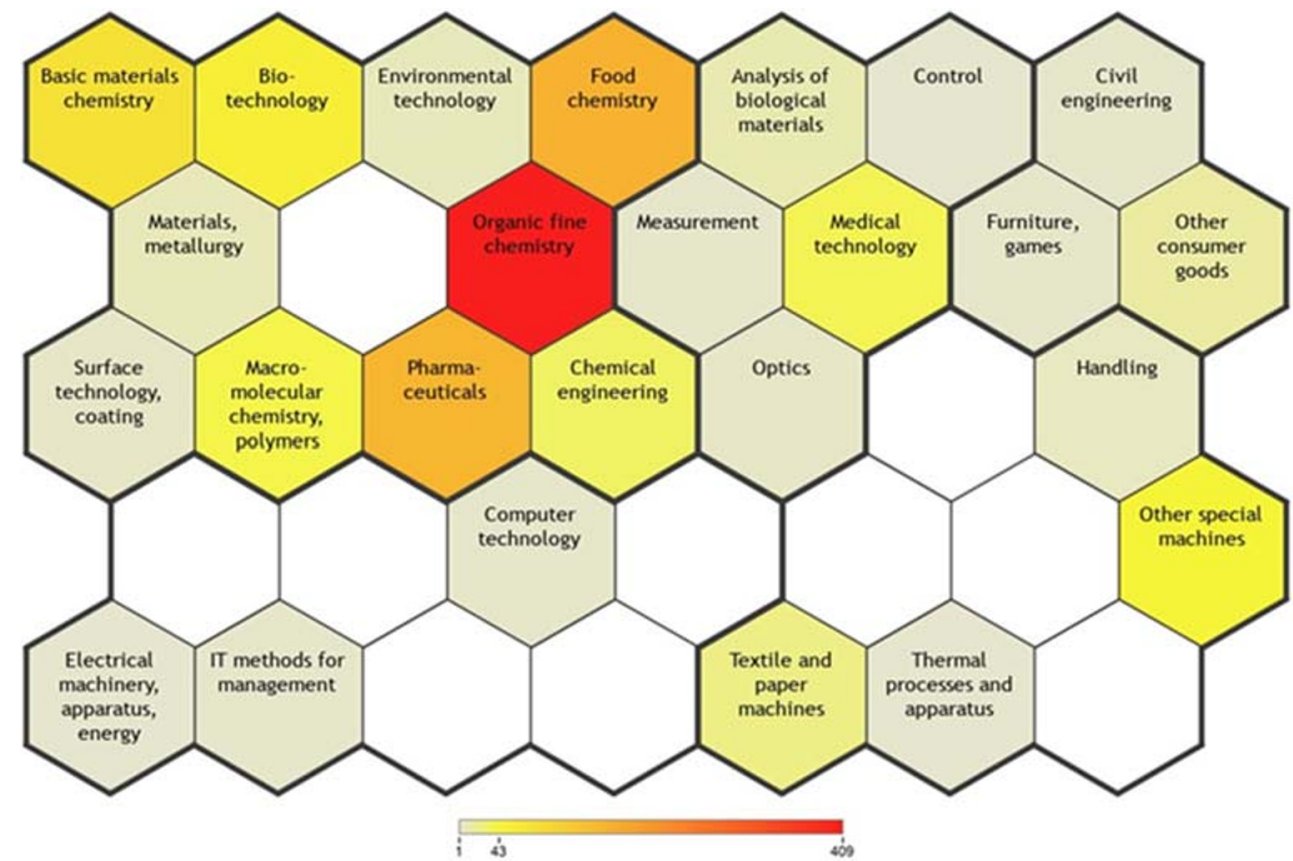


global value chain. This strategy of end-market upgrading (Gereffi and Fernandez-Stark 2016) requires development of new products aimed at higher end markets. In the case of kelp, traditionally, the focus has been on the food thickener market, but now, new application for cosmetics and pharmaceuticals is aimed for.

The increasing number of scientific publications and patents from Europe is evidence of this strategy being pursued. A quantitative analysis of scientific publications shows a difference between Asia and Europe where, despite the size of the sector in Asia, the number of international scientific publications from Asia is lower than from Europe. This reflects the 'research-driven' development of the seaweed sector in Europa. Yet, if the number of patents is taken into consideration, it becomes clear that innovation for high-value products is not a strategy exclusive to the European sector, see also the innovative alginate products developed by the Chinse Bright Moon Group (BMSG 2020). If the European sector is to benefit from this strategy, it is of pivotal importance to think about the protection of intellectual property and continue innovation to reduce the costs of production.

\section{Barriers for the European supply chains}

Working on removing barriers in the European supply chains is now one of the tasks for the near future. Barriers are found in the high cost of production; increasing consumer demand for seaweed-based products, concerns about food safety and environmental effects; and the competition, primarily with Asia. To bring the European seaweed sector further, innovation cannot focus on one or two issues. Following Barbier et al. (2019), we see opportunities in a better knowledge of current production yields at the European level, with homogenised measurements in biomass production. In addition, the (national) licensing procedures should be simplified for greater transparency and efficiency. Barbier et al. (2019) see this together with more promotion of the social acceptability of seaweed concessions, but also more knowledge and training facilities and programs for the whole industry, from policy makers, local authorities, researchers to the production sectors. Research into the consumer acceptance of seaweed can generate new insights to market seaweed as an attractive product.

To make sure innovations are aligned with the first needs of the sector and to make sure the entire value chain benefits from innovation, the existing cooperation mechanisms between sectors (including European research projects, networks and normalisation initiatives) are instrumental; they allow for relational governance whereby actors can coordinate, rather than compete on price.

An imminent question in relation to innovation is to what extent the European sector will be able to fence off the current dominant actors. European actors are active in patenting their innovation, also in the high-value segments such as cosmetics, although a few actors dominate patenting.

\section{Two alternative upgrading strategies}

The development of kelp-based products or intermediate products for high-value markets is not the only upgrading strategy imaginable. Looking at the developments in the sector and in scientific and policy debates, two alternative strategies are identified.

\section{High value: business-based value adding production and processing}

The first strategy includes those efforts to create higher value for European seaweed sector by demonstrating value adding characteristics such as better sustainability performance, better quality and food safety. As argued by Gereffi and FernandezStark (2016, 12): 'end-market upgrading, which can include moving into more sophisticated markets that require compliance with new, more rigorous standards'. Two developments are particularly relevant here. First, organic certification of seaweeds is possible since 2008. Commission Regulation $710 / 2009$ formulates the criteria to be met by seaweed producers and processors if they want to use the EU Organic label. Secondly, in 2017, the Aquaculture Stewardship Council (ASC) and Marine Stewardship Council (MSC) jointly developed the ASC-MSC Seaweed Standard to promote environmentally sustainable and social responsible use of seaweed resources.

\section{Sustainable quality: ecosystem services—value adding social and ecological benefits}

A last upgrading strategy deployed does not fit within the categories identified by Gereffi and Fernandez-Stark (2016). Scientific publications have not only investigated the positive impact of seaweed on water quality and ecosystem status but also studied use of seaweed for bioremediation and carbon sink (Wood et al. 2017; Elizondo-González et al. 2018; Hasselström et al. 2018). Krause-Jensen et al. (2018) argue that incorporation of seaweeds into carbon emission accounting is an imperative. This is echoed by companies and concerned governments that seek to create additional value to seaweed by showing and capitalising the contribution of seaweed to public policy objectives (food security, support local business, societal, ecological, regional development). For example, Gregersen (2018) suggest that 19 gigatonnes $\mathrm{CO}_{2}$ can be captured per year if $9 \%$ of the world's oceans are converted into seaweed farms. Van Swam (2018) explicitly links seaweed cultivation to the Paris Climate Accord, emphasising the positive contribution to sustainable and regional sourcing, support of marine ecosystem and the contribution to a varied 
and healthy diet. In sum, we can say that seaweed is now increasingly becoming interesting by entering new agendas which offer more prospects for business. Following Barbier et al. (2019), seaweed can play important roles in the support of complex food webs in coastal systems (habitat, food, reproductive refuge and shelter for many organisms - apex predators, fishes and invertebrates); coastal defence (reduction of hydrodynamic energy from waves \& coastal erosion); carbon sequestration and removal of dissolved nutrients (N \& $\mathrm{P}$ uptake).

\section{Conclusions}

This paper sought to analyse the upgrading strategy used by the European kelp sector, using the concepts of the global value chains framework (Gereffi et al. 2005; Gereffi and Fernandez-Stark 2016).

Our analysis started with the premise that European kelp sector aims to produce high-value products from seaweeds to set themselves apart from other produce, to avoid competition on the basis of low production costs. The analysis points towards various dividing lines between the established seaweed cultivation and processing industry in Asia and the (far smaller) nascent cultivation and processing industry for high-value applications. These are two unconnected worlds.

Inclusion in the existing global chain is not what the European kelp producers should aim for; the global chain is consolidated and features large, integrated companies who can deliver for lower prices than the European producers. The organisation of the global value chain lends considerable power to the Asian integrated firms, already producing and processing seaweeds at low costs.

Development of higher value products is the road currently pursued and requires the European seaweed producers and processors to establish working relationships to other value chain, such as the cosmetics and pharmaceutical value chain. This is exemplified by the increasing number of scientific publications and patents originating from Europe. The risk of science and innovation propelled growth of the sector is that market development is not sufficiently taken into account.

A further strengthening of relational value chains, including processors and retailers, is needed to ensure the products developed are desired, and in accordance with quality criteria used, by end-users. Chain or intra-sectoral upgrading could occur if European food sector engage more close with the European producers. Those bring financial power and a broader client base to the table and are instrumental in creating a relational value chain. Upgrading strategies setting European production apart from the current produce in Asia through certification and labelling or through rewarding benefits of production are other options to create more value for the European kelp sector.
Funding This project has received funding from the European Union's Horizon 2020 research and innovation programme under grant agreement No. 727892 (GENIALG) and the Knowledge Base Research program Marine Lower Trophic Food Systems (KB-34-007-0004). This output reflects only the author's view and the European Union cannot be held responsible for any use that may be made of the information contained therein.

Open Access This article is licensed under a Creative Commons Attribution 4.0 International License, which permits use, sharing, adaptation, distribution and reproduction in any medium or format, as long as you give appropriate credit to the original author(s) and the source, provide a link to the Creative Commons licence, and indicate if changes were made. The images or other third party material in this article are included in the article's Creative Commons licence, unless indicated otherwise in a credit line to the material. If material is not included in the article's Creative Commons licence and your intended use is not permitted by statutory regulation or exceeds the permitted use, you will need to obtain permission directly from the copyright holder. To view a copy of this licence, visit http://creativecommons.org/licenses/by/4.0/.

\section{References}

Adams JM, Gallagher JA, Donnison IS (2009) Fermentation study on Saccharina latissima for bioethanol production considering variable pre-treatments. J Appl Phycol 21:569-574

De Backer K, Miroudot S (2012) Mapping Global Value Chains. OECD Trade Policy Papers 159:1-44

Bak UG (2018) Production method and cost of commercial-scale offshore cultivation of kelp in the Faroe Islands using multiple partial harvesting. Algal Res 33:36-47

Barbier M, Charrier B, Araujo R, Holdt SL, Jacquemin B, Rebours C (2019) PEGASUS - PHYCOMORPH European guidelines for a sustainable aquaculture of seaweeds, COST Action FA1406 (M. Barbier and B. Charrier, Eds), Roscoff, France

Bindu MS, Levine IA (2011) The commercial red seaweed Kappaphycus alvarezii-an overview on farming and environment. J Appl Phycol 23:789-796

BMSG (2020) Bright Moon Seaweed Group. World-wide electronic publication. http://www.bmsg.com/en; searched on 21 September 2020

Broch OJ, Alver MO, Bekkby T, Gundersen H, Forbord S, Handå A, Skjermo J, Hancke K (2019) The kelp cultivation potential in coastal and offshore regions of Norway. Front Mar Sci 5:1-15

Buck BH, Krause G, Rosenthal H (2004) Extensive open ocean aquaculture development within wind farms in Germany: The prospect of offshore co-management and legal constraints. Ocean Coast Manage 47:95-122

van den Burg SW, van Duijn AP, Bartelings H, van Krimpen MM, Poelman M (2016) The economic feasibility of seaweed production in the North Sea. Aquacult Ecol Manag 20:235-252

Buschmann AH, López DA, Medina A (1996) A review of the environmental effects and alternative production strategies of marine aquaculture in Chile. Aquacult Eng 15:397-421

Buschmann AH, Camus C, Infante J, Neori A, Israel Á, HernándezGonzález MC, Pereda SV, Gomez-Pinchetti JL, Golberg A, Tadmor-Shalev N, Critchley AT (2017) Seaweed production: overview of the global state of exploitation, farming and emerging research activity. Eur J Phycol 52:391-406

Couteau C, Coiffard L (2016) Seaweed applications in cosmetics. In: Fleurence J, Levine I (eds) Seaweed in Health and Disease Prevention. Elsevier, Amsterdam, pp 423-441 
Ehrig K, Alban S (2015) Sulfated galactofucan from the brown alga Saccharina latissima-Variability of yield, structural composition and bioactivity. Mar Drugs 13:76-101

Elizondo-González R, Quiroz-Guzmán E, Escobedo-Fregoso C, Magallón-Servín P, Peña-Rodríguez A (2018) Use of seaweed Ulva lactuca for water bioremediation and as feed additive for white shrimp Litopenaeus vannamei. PeerJ 6:e4459

European Commission (2018) Blue bioeconomy: shape the future of the blue bioeconomy in Europe! World-wide electronic publication, European Commission. https://ec.europa.eu/maritimeaffairs/press/ blue-bioeconomy-forum-shape-future-blue-bioeconomy-europe en; searched on 4 September 2020

FAO (2020) "The state of world fisheries and aquaculture". Rome: Food and Agriculture Organisation of the United Nations. Available online: http://www.fao.org/publications/sofia/2020/en/

Gereffi G, Fernandez-Stark K (2016) Global value chains analysis: a primer, 2nd edn. Center on Globalization, Governance \& Competitiveness, Duke University, Durham, NC

Gereffi G, Humphrey J, Sturgeon T (2005) The Governance of global value chains. Rev Int Polit Econ 12:78-104

Gereffi G, Lee J (2016) Economic and social upgrading in global value chains and industrial clusters: why governance matters. J Bus Ethics 133:25-38

Gregersen O (2018) Seaweed cultivation and meaningful scale of economics. Presented at Seagriculture, Galway 6 November 2018

Hanbidge A, Potin P, Cascella K (2016) GENIALG. World-wide electronic publication, AquaTT. http://genialgproject.eu; searched on 21 September 2020

Hasselström L, Visch W, Gröndahl F, Nylund GM, Pavia H (2018) The impact of seaweed cultivation on ecosystem services - a case study from the west Coast of Sweden. Mar Pollut Bull 133:53-64

Helmes RJ, López-Contreras AM, Benoit M, Abreu H, Maguire J, Moejes F, van den Burg SW (2018) Environmental impacts of experimental production of lactic acid for bioplastics from Ulva spp. Sustainability 10:1-15

Humphrey J, Schmitz H (2002) Comment est-ce que l'insertion dans des chaînes de valeur mondiales influe sur la revalorisation des regroupements industriels? Reg Stud 36:1017-1027

Kang JY, Chun BS, Lee MC, Choi JS, Choi IS, Hong YK (2016) Antiinflammatory activity and chemical composition of essential oil extracted with supercritical $\mathrm{CO}_{2}$ from the brown seaweed Undaria pinnatifida. J Essent Oil Bear P1 19:46-51

Krause-Jensen D, Lavery P, Serrano O, Marba N, Masque P, Duarte CM (2018) Sequestration of macroalgal carbon: the elephant in the Blue Carbon room. Biol Letters 14:20180236

Lee KY, Mooney DJ (2013) Alginate: properties and biomedical applications. Prog Polym Sci 37:106-126

van Leeuwen J (2018) Upscaling seaweed cultivation and cooperation in Europe. Presented at Seagriculture, Galway 6 November 2018

Lüning K, Mortensen L (2015) European aquaculture of sugar kelp (Saccharina latissima) for food industries: iodine content and epiphytic animals as major problems. Bot Mar 58:449-455
Milberg W, Houston E (2005) The high road and the low road to international competitiveness: extending the neo-schumpeterian trade model beyond technology. Int Rev Appl Econ 19:137-162

Mac Monagail M, Cummins E, Bermejo R, Daly E, Costello D, Morrison L (2018) Quantification and feed to food transfer of total and inorganic arsenic from a commercial seaweed feed. Environ Int 118: 314-324

Msuya FE, Buriyo A, Omar I, Pascal B, Narrain K, Ravina JJM, Mrabu E, Wakibia JG (2014) Cultivation and utilisation of red seaweeds in the Western Indian Ocean (WIO) Region. J Appl Phycol 26:699705

Nayar S, Bott K (2014) Current status of global cultivated seaweed production and markets. World Aquac 45:32-37

News Desk (2018) Algaia secures $4 \mathrm{~m}$ euros to expand French algae facility. World-wide electronic publication, FoodBev Media. https://www.foodbev.com/news/algaia-secures-4m-euros-expandfrench-algae-facility/; search on 21 September 2020

Noordzeeboerderij (2020) Community het Zeewierplatform. World-wide electronic publication, Noordzeeboerderij. https://www. noordzeeboerderij.nl/community/zeewierplatform; searched on 21 September 2020

Porse H, Rudolph B (2017) The seaweed hydrocolloid industry: 2016 updates, requirements, and outlook. J Appl Phycol 29:2187-2200

Roleda MY, Marfaing H, Desnica N, Jónsdóttir R, Skjermo J, Rebours C, Nitschke U (2010) Variations in polyphenol and heavy metal contents of wild-harvested and cultivated seaweed bulk biomass: health risk assessment and implication for food applications. Food Control 95:121-134

Siddaway A (2014) What is a systematic literature review and how do I do one. University of Stirling pp 1-13

Stévant P, Rebours C, Chapman A (2017) Seaweed aquaculture in Norway: recent industrial developments and future perspectives. Aquacult Int 25:1373-1390

Tallman S, Luo Y, Buckley PJ (2018) Business models in global competition. Glob Strateg J 8:517-535

van den Broek W, van Swam K (2018) Proseaweed. World-wide electronic publication, Wageningen University and Research and Noordzeeboerderij. http://proseaweed.eu; searched on 21 September 2020

van Swam K (2018) Seaweed and the Paris climate accord. Presented at Seagriculture, Galway 6 November 2018

Wood D, Capuzzo E, Kirby D, Mooney-McAuley K, Kerrison P (2017) UK Macroalgae Aquaculture: What are the key environmental and licensing considerations? Mar Policy 83:29-39

Zhang J (2018) Seaweed industry in China. Innovation Norway, July 2nd, 2018, Beijing Available online: https://www.submariner-network. eu/images/grass/Seaweed_Industry_in_China.pdf

Publisher's note Springer Nature remains neutral with regard to jurisdictional claims in published maps and institutional affiliations. 